\title{
MELACAK INVESTASI SYARIAH: STUDI PERKEMBANGAN SUKUK BAGI PASAR MODAL SYARIAH DI INDONESIA
}

\author{
Afifatul Munawiroh, Fakultas Syariah Institut Agama Islam Negeri Jember, \\ e-mail: afifatulmunawiroh93@gmail.com \\ Rumawi, Fakultas Syariah Institut Agama Islam Negeri Jember, \\ e-mail: rumawi@iain-jember.ac.id
}

doi: https://doi.org/10.24843/KS.2020.v08.i10.p06

\begin{abstract}
Abstrak
Sukuk (Obligasi syariah) merupakan investasi yang ada dalam lingkup pasar modal syariah yang sangat menguntungkan. Oleh Karena itu, perlu adanya penelitian lanjutan supaya sukuk bisa meluas ke seluruh penjuru negeri. Paper ini adalah penelitian yang berbasis pada kajian pustaka, tema yang diambil dalam penelitian ini adalah Sukuk dalam Pasar Modal Syariah. Ada tiga pertanyaan penting: pertama, bagaimana kondisi pasar modal syariah di Indonesia? Kedua, bagaimana investasi syariah dalam mengelola perkembangan sukuk di Indonesia? Ketiga, bagaimana impact adanya sukuk bagi pasar modal syariah di Indonesia? Dengan pendekatan historis untuk mengkaji kondisi pasar modal syariah di Indonesia. Sedangkan, investasi syariah dalam mengelola perkembangan sukuk dan impact adanya sukuk bagi pasar modal syariah di Indonesia dijelaskan melalui pendekatan content analysis. Hasil dari pembahasan ini adalah penurunan dan peningkatan suku di Indonesia sangat berpengaruh terhadap kebutuhan dalam pengembangan Indonesia, terlebih negara ini dihuni oleh mayoritas penduduk muslim. Sehingga, dalam penyebarannya akan semakin cepat dan mudah.
\end{abstract}

Keywords: Investasi Syariah, Sukuk, Pasar Modal Syariah

\begin{abstract}
Sukuk (Islamic bonds) are investments that exist within the scope of the Islamic capital market which is very profitable. Therefore, further research is needed so that Sukuk can be spread throughout the country. This paper is a research-based on a literature review, the theme taken in this study is Sukuk in the Islamic Capital Market. There are three important questions: first, what is the condition of the Islamic capital market in Indonesia? Second, how is Islamic investment in managing the development of Sukuk in Indonesia? Third, what is the impact of the existence of Sukuk for the Islamic capital market in Indonesia? With a historical approach to assessing the condition of Islamic capital markets in Indonesia. Meanwhile, Islamic investment in managing the development of Sukuk and the impact of the existence of Sukuk for the Islamic capital market in Indonesia is explained through a content analysis approach. The result of this discussion is the decline and increase in ethnic groups in Indonesia is very influential on the needs in the development of Indonesia, moreover, the country is inhabited by a majority of the Muslim population. Thus, the spread will be faster and easier.
\end{abstract}

Keywords: Sharia Investment, Sukuk, Sharia Capital Market 


\section{Pendahuluan}

\subsection{Latar Belakang Masalah}

Pasar modal syariah dimulai dengan adanya Reksa Dana oleh PT. Danareksa Investment Management pada 3 Juli 1997. Selanjutnya, tepat tanggal 3 Juli 2000 telah terbit Jakarta Islamic Index (JII). ${ }^{1}$ Ada tiga macam yang diterbitkan pada saat itu, yaitu reksadana syariah, saham syariah yang lebih dikenal dengan Jakarta Islamic Index (JII), dan yang terakhir sukuk (obligasi syariah). Pasar modal syariah merupakan salah satu implementasi konkrit dari ekonomi syariah. Ibarat didirikan sebuah rumah ekonomi syariah, maka pasar modal syariah sebagai salah satu ruangan diantara beberapa ruang yang lain seperti bank syariah, akuntansi syariah, reksadana syariah, asuransi syariah dan lain-lain.

Oleh karena itu, pasar modal syariah tidak dapat dilepaskan dari ekonomi syariah. Pondasi filosofis yang menjadi dasar operasional pasar modal syariah adalah ekonomi syariah. Pasar modal syariah di Indonesia sebagai salah satu implementasi konkrit ekonomi syariah. Hal lainnya, karena perbankan syariah belum dikenal luas oleh masyarakat.

Meskipun kegiatan investasi syariah telah ditawarkan sejak tahun 1997 melalui instrument reksadana syariah dana syariah dan beberapa fatwa DSN MUI mengenai kegiatan investasi syariah di pasar modal. Ironis situasi ini bila dilihat dari jumlah penduduk Indonesia yang sebagian besar merupakan umat muslim. ${ }^{2}$ Lantas, investasi yang besar mendapat keuntungan adalah sukuk (obligasi syariah), patut digunakan dan diterapakan di Indonesia agar ekonomi menjadi lebih baik.

Mengatasi ekonomi nasional agar menjadi lebih baik, patut ditopang dengan munculnya pasar saham syariah, yang merupakan kunci untuk mengurangi risiko ketidakpastian dalam pasar modal konvensional dan juga bisa mengurangi skandal keuangan di pasar modal Internasional seperti dalam kasus WorldCom, Walt Disney, Enron, dan masih banyak juga yang lainnya. Tidak hanya dalam permasalahan itu, pasar modal syariah dapat menampung masyarakat dengan tidak memandang agama mereka dalam kegiatan memperoleh keuntungan dan risikonya, meningkatkan performa, kinerja dan sustainable dari perusahaan yang termasuk dalam bursa saham syariah sesuai dengan harga saham serta dapat mengurangi terjadinya spekulasi dalam pasar modal syariah. ${ }^{3}$

Investasi syariah sendiri merupakan menanamkan atau menempatkan asset, baik berupa harta maupun dana, pada sesuatu yang diharapkan dapat memberikan hasil pendapatan atau akan meningkatkan nilainya di masa mendatang. Atau secara sederhananya, investasi berarti mengubah cashflow agar mendapatkan keuntungan/jumlah yang lebih besar di kemudian hari. Sedangkan investasi keuangan adalah menanamkan dana pada surat berharga (financial asset) yang diharapkan akan meningkat nilainya di masa mendatang. Kegiatan investasi keuangan syariah pada prinsipnya adalah harus terkait secara langsung dengan suatu asset atau kegiatan

${ }^{1}$ Devi Dwi Kurniawati, "Analisis Perkembangan Sukuk (Obligasi Syariah) Dan Dampaknya Bagi Pasar Modal Syariah," Al-Iqtishad (2013).

2Fadilla Fadilla, "Pasar Modal Syariah Dan Konvensional," Islamic Banking: Jurnal Pemikiran dan Pengembangan Perbankan Syariah (2018).

${ }^{3}$ Ahmad Dahlan Malik, "ANALISA FAKTOR - FAKTOR YANG MEMPENGARUHI MINAT MASYARAKAT BERINVESTASI DI PASAR MODAL SYARIAH MELALUI BURSA GALERI INVESTASI UISI," Jurnal Ekonomi dan Bisnis Islam (Journal of Islamic Economics and Business) (2017). 
usaha yang spesifik dan menghasilkan manfaat, karena hanya atas manfaat tersebut dapat dilakukan sistem bagi hasil. ${ }^{4}$

Produk yang dihasilkan dari pasar modal syariah tersebut, antara lain berupa surat berharga atau Efek. Ditinjau di dalam Undang-Undang Nomor 8 Tahun 1995 tentang Pasar Modal. Efek adalah surat berharga atau surat pengakuan utang surat berharga komersial, saham, obligasi, tanda bukti utang. Unit penyertaan kontrak investasi kolektif kontrak berjangka atas efek, dan setiap derivative dari efek. Sejalan dari definisi yang dipaparkan tersebut, maka produk syariah yang berupa efek harus tidak bertentangan dengan prinsip-prinsip syariah. Oleh karena itu, efek tersebut dapat dikatakan Efek Syariah. ${ }^{5}$

Dalam peraturan Bapepam dan LK Nomor IX.A.13 tentang Penerbitan Efek Syariah disebut bahwa Efek Syariah adalah efek sebagaimana yang dimaksud dalam UUPM dan peraturan pelaksanaannya akad, cara dan kegiatan usaha yang menjadi landasan pelaksanaannya tidak bertentangan dengan prinsip-prinsip dari pasar modal. Sampai sekarang, Efek syariah telah yang telah diterbitkan di pasar modal Indonesia meliputi Saham Syariah, Sukuk, dan Unit Penyertaan dari Reksa Dana Syariah. ${ }^{6}$

Sebagai upaya mengetahui tingkat perkembangan pasar modal syariah di Indonesia, maka perlu adanya data-data yang sangat rinci dan juga data mengenai pasar investasi keuangan yang bisa memberikan jaminan halal atau kebolehan. Jaminan tersebut diatur dalam dasar hukum pasar modal syariah di Indonesia yang mengacu pada peraturan otoritas jasa keuangan yang terdiri dari POJK No. 15 tahun 2015 tentang penerapan prinsip syariah di pasar modal, POJK No. 17 tahun2015 tentang penerbitan dan persyaratan efek syariah ahli syariah pasar modal, POJK No. 17 tahun 2015 tentang penerbitan dan persyaratan efek syariah berupa saham oleh emiten syariah atau perusahaan publik syariah, POJK No. 18 tahun2015 tentang penerbitan dan persyaratan sukuk, POJK No. 19 tahun2015 tentang penerbitan dan persyaratan reksa dana syariah dan POJK No. 20 tahun2015 tentang penerbitan dan persyaratan efek beragun asset syariah.

\subsection{Rumusan Masalah}

Adapun beberapa pertanyaan yang menjadi permasalahan dalam penelitian ini adalah sebagai berikut:

1.1 Bagaimana historis pasar modal konvensional hingga pasar modal syariah di Indonesia?

1.2 Bagaimana perkembangan obligasi syariah (sukuk) di Indonesia?

1.3 Bagaimana dampak sukuk bagi pasar modal syariah di Indonesia?

Pertanyaan ini diajukan untuk mengetahui secara mendalam terkait kondisi pasar modal di Indonesia, untuk menentukan cara dan siasat perkembangan pasar modal yang lebih tepat seperti apa yang patut diteruskan di Indonesia. Sedangkan,

${ }^{4} Y u k e$ Rahmawati, "Resosialisasi Investasi Keuangan Syariah," Al-Iqtishad: Jurnal Ilmu Ekonomi Syariah (2009).

${ }^{5}$ Malik, "Analisa Faktor - Faktor Yang Mempengaruhi Minat Masyarakat Berinvestasi Di Pasar Modal Syariah Melalui Bursa Galeri Investasi Uisi."

6OJK, Pasar Modal Syariah, Jakarta, (2016). https://www.ojk.go.id/id/kanal/syariah/tentang-syariah/pages/pasar-modal-syariah.aspx, diakses pada tanggal 1 Juni 2020 Pukul 15.03 WIB. 
alur juga presentase perkembangan pasar modal di Indonesia dengan menyisir hasil yang telah lalu proses perkembangan di Indonesia dijelaskan dengan awal mula pertanyaan investasi syariah dalam mengelola perkembangan sukuk di Indonesia.

\subsection{Tujuan penelitian}

Penelitian ini mencoba untuk menjabarkan dan juga melacak mengenai Investasi Syariah yang berfokus pada perkembangan Sukuk bagi Pasar Modal Syariah di Indonesia. Penelitian ini dilakukan untuk melihat lebih jauh perkembangan sukuk, dampak dari perkembangan atau adanya penurunan dalam sukuk, mempelajari lebih dalam mengenai pasar modal, dan juga investasi syariah yang berkembang di Indonesia. Karena perkembangan terkait sukuk sangat berdampak terhadap negara Indonesia. Jika nantinya, ada penurunan sukuk dapat dipastikan ada sesuatu yang tidak tepat atau kurangnya pemahaman Sukuk terhadap seluruh masyarakat Indonesia.

Dalam membahas implikasi sukuk dalam pasar modal di Indonesia menjadi pengaruh besar terhadap perkembangan negara ini juga. Karena dengan mengetahui dampak dari sukuk dalam pasar modal ini, lebih mudah pengaturan setelahnya untuk mengetahui hambatan-hambatan dari dijalankannya Sukuk di Indonesia dan ini dalam sebuah pertanyaan yang akan dibahas, bagaimana impact adanya sukuk bagi pasar modal syariah di Indonesia? Karena sangat penting mengetahui implikasi dari suatu perkembangan pasar modal syariah di Indonesia.

\section{Metode penelitian}

Penelitian ini adalah penelitian kajian normatif, dimana tidak perlu membenarkan temuan para ahli hukum, karena mengkaji secara mendalam terkait Investasi Syariah: Studi Perkembangan Sukuk bagi Pasar Modal di Indonesia. ${ }^{7}$ Adapun untuk memperoleh hasil yang komprehensif, penelitian ini menggunakan dua pendekatan yang terdiri dari pendekatan historis dan analysis content. Dalam pendekatan sosio historis menyoroti aspek sosiologis dan historis dari hukum mulai dari kehidupan para Nabi hingga jatuh pada era dinamika Islam kontemporer dan juga menjelaskan Investasi Syariah yang berlaku dalam kehidupan masyarakat dan juga meneliti kebiasaan ataupun adat dalam transaksi investasi syariah yang berlaku di masyarakat pada umumnya.

Dalam pendekatan ini terdiri dari tiga aspek: pertama aspek filosofis yang merupakan jawaban terhadap hukum kontemporer; kedua, aspek yuridis yang menjadi alasan kuat untuk mengatasi isu-isu umat Islam saat ini; dan yang ketiga, aspek sosiologis sebagai pedoman kehidupan bagi masyarakat Indonesia. ${ }^{8}$ Sedangkan, dalam pendekatan analysis content merujuk terhadap perundang-undangan dan juga hukum-hukum dari Otoritas Jasa Keuangan. yang meneliti secara kritis di dalam jurnal, buku-buku, perundang-undangan dan juga dokumen-dokumen yang mengulas tentang Investasi Syariah yang menitik beratkan pada permasalahan Obligasi Syariah. Selain itu, juga digunakan kamus ensiklopedia sebagai bahan hukum tersier. ${ }^{9}$

${ }^{7}$ M. Wahib Aziz, "Wakaf Tunai Dalam Perspektif Hukum Islam," International Journal Ihya' 'Ulum al-Din (2017).

${ }^{8}$ Ibnu Elmi dan Jefri Tarantang, "Fatwa Majelis Ulama sebagai Solusi Permasalahan Umat di Indonesia", Proceding Majelis Ulama Indonesia (2019).

${ }^{9}$ Erie Hariyanto, “BURGELIJK WETBOEK (Menelusuri Sejarah Hukum Pemberlakuannya Di Indonesia)," Al-Ihkam: Jurnal Hukum dan Pranata Sosial (2013). 


\section{Hasil dan Pembahasan}

\subsection{Historis pasar modal konvensional hingga pasar modal syariah di Indonesia Pasar Modal Konvensional}

Pada tahun 1892, perusahaan perkebunan yang bernama Cultuur Maatschappij Goalpara di Batavia yang mengeluarkan penjualan 400 saham dengan harga 500 gulden per sahamnya. Lantas, pada tahun 1896, prospektus penjualan saham senilai 105 ribu gulden dengan harga perdana 100 gulden per saham yang dikeluarkan oleh Het Centrum dari Djoejacarta. Akan tetapi, tidak ada keterangan apakah saham tersebut dapat diperjualbelikan. Kemungkinan besar, yang diperjualbelikan adalah saham yang telah terdaftar di bursa Amsterdam. Letaknya ada di Batavia, Semarang, dan Surabaya. Dan dapat dikatakan bahwa ini adalah periode permulaan sejarah pasar modal di Indonesia.

Pemerintah kolonial Belanda, sekitar pada awal abad ke-19 mulai membangun perkebunan secara besar-besaran di Indonesia, merupakan salah satu sumber dana dari para penabung yang telah distrategikan dengan baik. Orang yang menabung terdiri dari orang-orang Belanda dan Eropa yang secara penghasilan lebih tinggi daripada pribumi. Atas dasar tersebut, maka pemerintahan kolonial waktu itu mendirikan pasar modal. Setelah itu, didirikan Amsterdamse Effectenbueurs mendirikan cabang yang terletak di Batavia pada tanggal 14 Desember 1912. ${ }^{10}$

Perkembangan pasar modal konvensional di Indonesia sudah dimulai sejak tahun 1912. Produk yang diperdagangkan pada masa itu adalah saham dan obligasi perusahaan-perusahaan Belanda dan pemerintaha Hindia Belanda. Akan tetapi, aktivitas pasar modal tersebut berhenti ketika terjadi perang dunia kedua. Kegiatan bursa efek dibuka kembali setelah Indonesia memperoleh kemerdekaan dengan diterbitkannnya obligasi pemerintah Indonesia tahun 1950. Aktifnya kembali pasar modal didukung dengan UU Darurat 3 tentang Bursa No 13 Tahun 1951 yang kemudian ditetapkan dengan UU No.15 tahun 1952.

Untuk meningkatkan aktivitas pasar modal pemerintah membentuk Badan Pelaksana Pasar Modal (BAPEPAM) yang kemudian diubah menjadi Badan Pengawas Pasar Modal. Untuk mempengaruhi perusahaan melakukan emisi pemerintah memberikan keringanan atas pajak perseroan sebesar $10-20 \%$ selama 5 tahun sejak perusahaan yang bersangkutan berhasil go public. ${ }^{11}$

Pasar modal di Indonesia berada di bawah naungan Otoritas Jasa Keuangan. Adapun instrument dari pasar modal sendiri ada dua yaitu; pertama, saham (stock) merupakan surat berharga yang bersifat kepemilikan. Dalam artian pemilik perusahaan. Semakin besar saham yang dimilikinya, maka semakin besar pula kekuasannya di perusahaan itu. Keuntungan dalam saham di kenal dengan sebutan deviden. Kedua, surat berharga atau obligasi merupakan instrument utang bagi perusahaan yang akan memperoleh modal. Secara ringkas, obligasi adalah utang dalam bentuk sekuriti. Penerbit obligasi adalah seorang peminjam atau debitor. Sedangkan, pemegang obligasi adalah pemberi pinjaman atau kreditor dan kupon obligasi adalah bunga pinjaman yang harus dibayarkan oleh debitor kepada kreditor.

${ }^{10}$ Yenni Samri Juliati, "Peranan Pasar Modal Dalam Perekonomian Negara," HUMAN FALAH: Jurnal Ekonomi dan Bisnis Islam (2015).

${ }^{11}$ Fadilla, "Pasar Modal Syariah Dan Konvensional." 
Dengan adanya obligasi ini, mungkin penerbit obligasi memperoleh pembayaran investasi jangka panjang dengan sumber dana dari laur perusahaan. ${ }^{12}$

Dari data-data tersebut dapat diketahui bahwa pasar modal berperan penting dalam perekonomian Negara, sebelum Negara Indonesia merdeka, lebih tepatnya pada masa pemerintahan kolonial mereka juga menggunakan pasar modal untuk mendapatkan dana yang diperlukan dalam proses pemerintahannya. ${ }^{13}$ Setelah mengetahui dampak sedikit ari pasar modal syariah maka investasi ini tetap digunakan di Indonesia. Dan sekarang lebih dijabarkan lagi, pasar modal yang berdasarkan dasar agama Islam, yang sering dikenal dengan pasar modal syariah.

\section{Pasar Modal Syariah}

Pasar modal syariah diresmikan pada tanggal 14 Maret 2003 oleh Menteri Keuangan Boediono dan didampingi oleh ketua Bapepam Herwidayatno, wakil dari MUI, wakil DSN dari direksi SRO, direksi perusahaan efek, pengurus organisasi pelaku dan Dewan Syariah Nasional belum merasa siap akan hal ini. Hal ini berkaitan dengan banyaknya kendala yang belum selesai dibahas. Sebelumnya, Bapepam telah mengkaji cukup lama dan bahkan telah mengirim delegasi untuk studi banding dan melihat mekanisme operasinya pasar modal syariah di berbagai pasar modal syariah dunia. ${ }^{14}$

Pada dasarnya, pasar modal syariah sama dengan pasar modal konvensional. Hanya saja, perbedaan diantara keduannya adalah dalam pasar modal syariah harus datang dari emiten yang memenuhi kriteria-kriteria syariah. Dengan demikian, saham syariah merupakan surat berharga yang melibatkan modal kedalam suatu perusahaan. Maka dari itu, dalam prinsip syariah dapat dilakukan dengan beberapa perusahan yang tidak melanggar ketentuan-ketentuan syariah. Seperti; Maisir, Gharar, Riba, Perjudian, dan memproduksi barang-barang yang diharamkan. Transaksi di dalam pasar modal diperbolehkan selama tidak bertentangan dengan ketentuan yang telah digariskan oleh syariah. Menurut Syed Othman Alhabshi pasar modal yang sesuai dengan prinsip syariah secara optimal dapat berperan terhadap pertumbuhan dan ekspansi ekonomi. Dalam analisisnya, menggunakan pendekatan penerapan prinsipprinsip syariah dalam aktivitas transaksi di pasar modal yang berorientasi kepada tujuan dari penerapan prinsip-prinsip syariah itu sendiri. Menurutnya, tujuan-tujuan syariah dalam kehidupan ekonomi tersebut terealisasi distribusi pendapatan dan kekayaan, terciptanya keadilan dan keseimbangan ekonomi baru akan terwujud dengan diaplikasikannya prinsip-prinsip syariah dalam berbagai aktivitas ekonomi dan keuangan syariah, khususnya pasar modal syariah. ${ }^{15}$

Pasar modal syariah adalah pasar modal yang mekanisme kegiatannya mengenai emiten, jenis efek yang diperdagangkan dan mekanisme perdagangannya telah sesuai dengan prinsip-prinsip syariah. Sedangkan, maksud efek syariah adalah sebagaimana yang dilihat dalam peraturan perundang-undangan di bidang pasar modal yang menggunakan prinsip-prinsip syariah. Adapun, maksud efek syariah menurut Fatwa

\footnotetext{
12Syaeful Bakhri, "Minat Mahasiswa Dalam Investasi Di Pasar Modal," Al-Amwal : Jurnal Ekonomi dan Perbankan Syari'ah (2018).

13Juliati, "Peranan Pasar Modal Dalam Perekonomian Negara."

${ }^{14}$ M Fauzan and Dedi Suhendro, "Peran Pasar Modal Syariah Dalam Mendorong Laju Pertumbuhan Ekonomi Di Indonesia," Prosiding SENDI (2019).

${ }^{15}$ Muhammad Yafiz, "Saham Dan Pasar Modal Syariah: Konsep, Sejarah Dan Perkembangannya," Miqot: Jurnal Ilmu-Ilmu Keislaman (2008).
} 
DSN MUI No.40/DSN-MUI/X/2003 tentang pasar modal dan pedoman umum penerapan prinsip syariah di bidang pasar modal yang mencakup saham syariah, reksadana syariah, kontrak investasi, kolektif efek beragunan asset syariah, dan surat berharga lainnya yang sesuai dengan prinsip-prinsip syariah. Akhir ini, instrument keuangan syariah bertambah dengan adanya fatwa DSN-MUI Nomor: 65/DSNMUI/III/2008 tentang Hak Memesan Efek Terlebih Dahulu (HMETD)Syariah, fatwa DSN-MUINomor: 66/DSN-MUI/III/2008 tentang Waran Syariah pada tanggal 6 Maret 2008, fatwa DSN-MUI Nomor: 69tahun 2008 tentang Surat Berharga Syariah Negara. Adapun, instrument-instrumen pasar modal syariah adalah saham syariah, obligasi syariah (sukuk) dan reksadana syariah. ${ }^{16}$

Dilihat dari historis yang dijabarkan di atas, pasar modal syariah merupakan pasar yang baru berkembang dan baru dikenal oleh masyarakat Indonesia, jika hanya dibandingkan dengan pasar modal konvensional yang sudah ada sejak zaman kolonial Belanda. Dengan demikian, adanya kebijakan dari otoritas bursa dapat digunakan untuk meningkatkan peran serta berbagai pihak dalam memajukan pasar modal syariah, maka prospek kerja ke depan pasar modal syariah di Indonesia sangat terbuka lebar untuk menjadi salah satu investasi dunia yang paling baik. ${ }^{17}$ Melihat dalam pasar modal syariah yang memiliki keberagaman, maka untuk penelitian ini focus terhadap obligasi syariah dalam pasar modal syariah.

\subsection{Perkembangan obligasi syariah (sukuk) di Indonesia}

Sejak awal diluncurkan reksadana syariah pada tanggal 25 Juni 1997, perkembangan instrument syariah terus mengalami perkembangan walaupun sedikit lambat. Akan tetapi pasti mengalami kenaikan yang cukup siginifikan. Jika ditinjau dari jumlah penduduk Indonesia dan peningkatan jumlah penduduk kelas menengah kepada kelas atas, penduduk Indonesia memiliki potensi yang cukup signifikan sebagai investor di dalam pasar modal. Indonesia sendiri merupakan sebuah negara dengan penduduk yang mayoritas adalah muslim.

Oleh karena itu, industri pasar modal syariah diharapkan dapat menjembatani dan sekaligus melibatkan peran serta dari masyarakat muslim untuk ikut aktif menjadi pelaku utama pasar terutama sebagai investor lokal di pasar modal. Hal ini, diikuti oleh keinginan pemerintah yang bertekad untuk meningkatkan perekonomian makro termasuk juga ekonomi syariah, yang diharapkan dapat berimbas terhadap sector riil secara signifikan. ${ }^{18}$

Berikut ini merupakan tabel perbedaan sukuk dengan obligasi konvesional sebagai berikut:

${ }^{16}$ Fauzan and Suhendro, "Peran Pasar Modal Syariah Dalam Mendorong Laju Pertumbuhan Ekonomi Di Indonesia."

${ }^{17 Y a f i z, ~ " S a h a m ~ D a n ~ P a s a r ~ M o d a l ~ S y a r i a h: ~ K o n s e p, ~ S e j a r a h ~ D a n ~ P e r k e m b a n g a n n y a . " ~}$

${ }^{18}$ hadi Peristiwo, "Analisis Minat Investor Di Kota Serang Terhadap Investasi Syariah Pada Pasar Modal Syariah," Islamiconomic: Jurnal Ekonomi Islam (2016). 


\begin{tabular}{|c|c|c|}
\hline Keterangan & Sukuk & Obligasi Konvesional \\
\hline Penerbit & Pemerintah dan korporasi & Pemerintah dan korporasi \\
\hline Sifat Instrumen & $\begin{array}{l}\text { Sertifikat kepemilikan atas } \\
\text { suatu asset }\end{array}$ & $\begin{array}{l}\text { Instrumen pengakuan } \\
\text { utang }\end{array}$ \\
\hline Penghasilan & $\begin{array}{l}\text { Imbalan, bagi hasil dan } \\
\text { margin }\end{array}$ & Bunga/kupon, capital gain \\
\hline Jangka Waktu & Pendek dan menengah & Menengah dan panjang \\
\hline Underlying Asset & Perlu & Tidak perlu \\
\hline Pihak yang terkait & $\begin{array}{l}\text { Obligator, SPV, Investor, dan } \\
\text { Trustee }\end{array}$ & $\begin{array}{l}\text { Obligator/Issue dan } \\
\text { Investor }\end{array}$ \\
\hline Jaminan & Berupa hak & Pada umumnya tidak ada \\
\hline Jenis Investor & Syariah dan Konvesional & Konvesional \\
\hline Tujuan & Sesuai dengan syariah & $\begin{array}{l}\text { Dapat digunakan untuk } \\
\text { tujuan apapun }\end{array}$ \\
\hline Klaim & $\begin{array}{l}\text { Klaim kepemilikan terhadap } \\
\text { asset, proyek, atau jasa yang } \\
\text { menjadi objek kontrak }\end{array}$ & $\begin{array}{l}\text { Klaim kreditor terhadap } \\
\text { entitas yang dipinjamkan } \\
\text { dan di beberapa kasus } \\
\text { terhadap aset }\end{array}$ \\
\hline Fatwa DSN & $\begin{array}{l}\text { No. 33/DSN-MUI/X/2002 } \\
\text { Obligasi Syariah Mudharabah } \\
\text { No.41/DSN-MUI/III/2004 } \\
\text { Obligasi Syariah Ijarah }\end{array}$ & Tidak ada \\
\hline
\end{tabular}

Sumber: www.ojk.go.id

Obligasi berawal dari kata Obligatie atau obligaat dalam terjemahan Bahasa Belanda, yaitu surat hutang suatu pinjaman Negara atau daerah atau persoalan dengan bunga tetap. Menurut UU Pasar Modal No. 8 tahun 1995, obligasi konvensional yaitu surat berharga jangka panjang yang bersifat hutang dan dikeluarkan oleh emiten kepada pemegang obligasi dengan kewajiban membayar bunga pada periode tertentu dan melunasi pokok pada saat jatuh tempo.

Sedangkan, obligasi syariah sesuai dengan fatwa DSN No.32 tahun 2002 adalah surat berharga jangka panjang berdasarkan prinsip syariah yang dikeluarkan emiten kepada pemegang obligasi syariah dengan mewajibkan emiten untuk membayar pendapatan kepada pemegang obligasi syariah berupa bagi hasil, serta membayar kembali dana obligasi pada saat jatuh tempo.

Dalam perkembangan sistem ekonomi syariah di Indonesia, salah satu lembaga yang juga ikut berkembang yaitu pasar modal. Pasar modal selama ini dikenal dengan transaksi jual beli efek seperti: saham, obligasi, reksadana, dan deviratif, kini mesti dimarakkan oleh transaksi produk keuangan baru yang berbasis syariah. Salah satu diantaranya adalah obligasi syariah atau sering juga disebut sukuk. Sukuk berasal dari 
akar kata Bahasa arab, yaitu sakk, ketika jamak berarti sukuk atau sakaik yang artinya memukul, membentur, atau menempa. ${ }^{19}$

Sukuk merupakan salah satu instrument investasi yang memberikan peluang bagi investor muslim maupun non muslim untuk memulai berinvestasi di Indonesia. Sehingga, adanya sukuk dapat dimanfaatkan untuk membangun perekonomian bangsa dan menciptakan kesejahteraan bagi masyarakat luas. Fakta selama ini menunjukkan bahwasanya pasar modal sangat responsive terhadap penerbitan sukuk. Hampir seluruh sukuk yang diterbitkan, diserap habis oleh pasar. Bahkan, ada beberapa kasus menimbulkan kelebihan permintaan. ${ }^{20}$

Semangat dan optimisme terhadap perkembangan sukuk di Indonesia juga dapat dilihat dari keikutsertaan Bapepam dan LK sebagai regulator di pasar modal Indonesia dengan mengeluarkan peraturan tentang obligasi syariah, yaitu peraturan nomor IX.A.13 yang mengatur tentang akad-akad yang digunakan dalam penerbitan efek syariah di pasar modal. Dengan diberlakukannya UU Sukuk Negara dapat diperkirakan perkembangan pasar sukuk di Indonesia bakal semarak dibandingkan sebelum-sebelumnya. Terlebih lagi, minat investor terhadap pengelolaan dan penerbitan sukuk ini sangat besar, sebagaimana ditunjukkan dari perkembangan sukuk global saat ini. ${ }^{21}$

Berikut ini merupakan data perkembangan sukuk di Indonesia sebagai berikut:

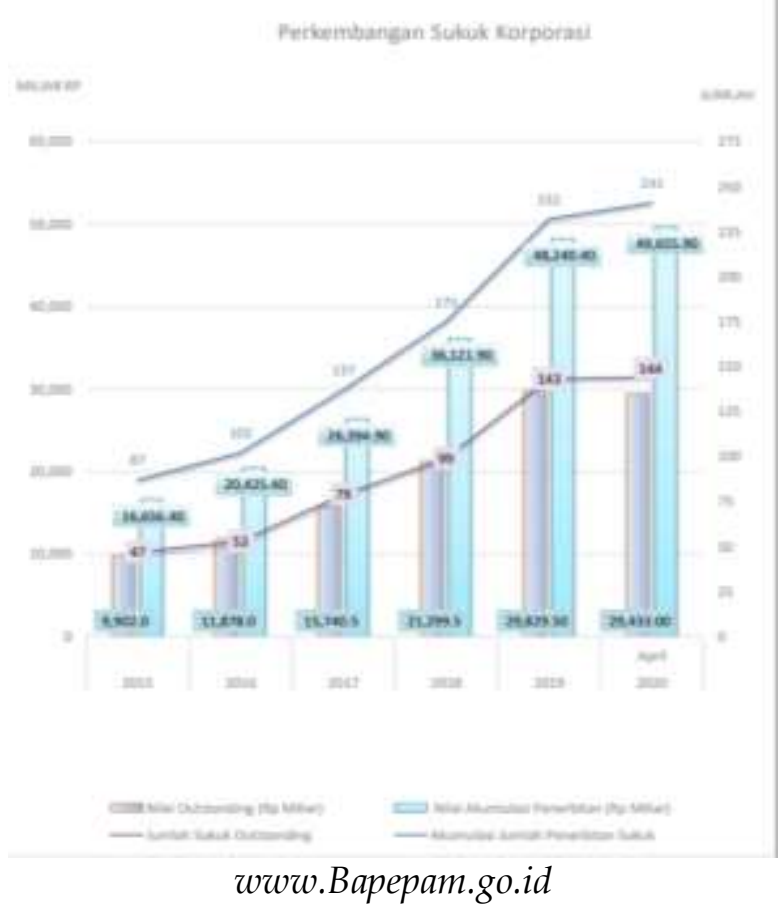

Dari data di atas bisa dilihat bahwasannya perkembangan sukuk di Indonesia mengalami peningkatan setiap tahunnya. Kenaikan terbanyak pada tahun 2019, sedangkan kenaikan paling sedikit terdapat peningkatan pada tahun 2020 tahun ini. Mungkin, akan terus terjadi peningkatan lagi di bulan-bulan kedepannya. Walaupun tingkat kenaikan sukuk di Indonesia belum teratur, tetapi itu sudah menjadi angina

${ }^{19}$ Muhammad Habibullah Aminy,Laili Hurriati -, "Perkembangan Obligasi Syariah (Sukuk) Di Indonesia," Iqtishaduna (2018).

${ }^{20}$ Dede Abdul Fatah, "Perkembangan Obligasi Syari'ah (Sukuk) Di Indonesia: Analisis Peluang Dan Tantangan," Al-'Adalah (2011).

21_, "PERKEMBANGAN OBLIGASI SYARIAH (SUKUK) DI INDONESIA." 
segar bahwasannya sukuk di Indonesia memerikan dampak positif terhadap perekonomian negara.

Bapepam menjelaskan tentang beberapa faktor yang menjadi sebab rendahnya penerbitan sukuk tersebut diantaranya kondisi ekonomi secara umum, pemahaman manajemen terhadap sukuk, proses penerbitan sukuk, dan aspek perpajakan dalam penerbitan sukuk. Selain itu, terdapat factor yang secara tidak langsung terkait dengan likuiditas pasar sekunder sukuk, yaitu: pertama, masih terbatasnya penerbitan sukuk korporasi di Indonesia baik dari aspek jumlah, variasi tenor maupun jenis akad. Kedua, masih kurangnya pemahaman investor terhadap perdagangan sukuk korporasi di pasar sekunder. Ketiga, penerbitan sukuk korporasi masih ditawarkan tidak secara detail kepada investor atau individu dengan nilai nominal yang relative besar, walaupun beberapa regulasi yang telah ada cukup memfasilitasi untuk dijadikan sebagai landasan dalam penerbitan sukuk korporasi ritel. Keempat, mayoritas karakter investor sukuk merupakan investor institusi lokal seperti perusahaan Asuransi, Dana Pensiun, dan dana reksas yang terstruktur memiliki kecenderungan membeli untuk di simpan hingga jaruh tempo. ${ }^{22}$

Adapun, sukuk yang banyak digunakan di Indonesia adalah sukuk dengan akad ijarah, kemudian yang kedua banyak diminati oleh investor adalah sukuk dengan akad mudharabah. Dan yang ketiga, paling sedikit diminati para investor adalah sukuk dengan jenis akad sukuk wakalah.

\section{Sukuk Ijarah}

Adapun macam-macam sukuk yang dijalankan di Indonesia ada dua, yaitu sukuk ijarah dan sukuk mudharabah. Sukuk Ijarah, menurut Ayub kontrak Iajrah (kontrak sewa) memiliki system yang fleksibel yaitu pembayaran sewa dapat tidak mengikuti periode masa manfaat asset, pembayaran sewa dapat dilakukan sebelum periode sewa, selama periode sewa atau setelah periode sewa. Hal ini disebabkan Karena factor utama dari likuiditas manajemen kontrak Ijarah adalah sekuritisasi.

Dalam akad Ijarah, pihak yang memberikan sewa harus memiliki sepenuhnya barang atau asset uang disewakan kepada penyewa. Dari manfaat asset tersebut, penyewa akan membayarkan upah kepada pihak yang memberikan sewa. Sewa dibayarkan sesuai dengan penghasilan yang didapatkan penyewa dari pemanfaatan asset yang disewa. Dalam hal ini, risiko terletak kepada keahlian dan kepiawaian penyewa dalam memanfaatkan asset dan bukan pada kegiatan spekulatif yang tidak memiliki keuntungan ekonomi riil.23

Di lansir dari POJK No. 53/POJK.04/2015 tentang akad yang digunakan dalam penerbitan efek syariah di pasar modal, menjelaskan Ijarah adalah perjanjian (akad) antara pihak pemberi sewa atau pemberi jasa (mu'jir) dan pihak penyewa atau pengguna jasa (musta'jir) untuk memindahkan hak guna (manfaat) atas suatu objek Iajrah yang dapat berupa manfaat barang dan/atau jasa dalam waktu tertentu dengan pembayaran sewa dan/atau upah (ujrah) tanpa diikuti dengan pemindahan kepemilikan objek Ijarah itu sendiri. ${ }^{24}$

\footnotetext{
${ }^{22}$ Kurniawati, "Analisis Perkembangan Sukuk (Obligasi Syariah) Dan Dampaknya Bagi Pasar Modal Syariah."

${ }^{23}$ Eka Siskawati, "Perkembangan Obligasi Syariah Di Indonesia: Suatu Tinjauan," Jurnal Akuntansi \& Manajemen (2010).

24 OJK (2015), https: ojk.go.id, diakses pada tanggal 2 Juni 2020 pukul 20.08 WIB
} 
Obligasi ijarah (ijarah bond) merupakan bentuk transaksi obligasi dengan system pemilik modal menyewakan modalnya dalam bentuk sekuritas yang kemudian digunakan oleh emiten untuk membiayai proyek atau mengembangkan perusahaan dengan memberikan harga sewa dan masa penyewaan yang telah disepakati dengan kontrak di depan. Keuntungan yang diperoleh oleh pemilik modal dengan menerima sewa atas sekuritas yang dimilikinya dan keuntungan bagi penyewa mendapatkan sekuritas dalam bentuk dana segar yang dapat digunakan kapan pun. ${ }^{25}$

Berikut ini contoh skema dari Sukuk Ijarah sebagai berikut:
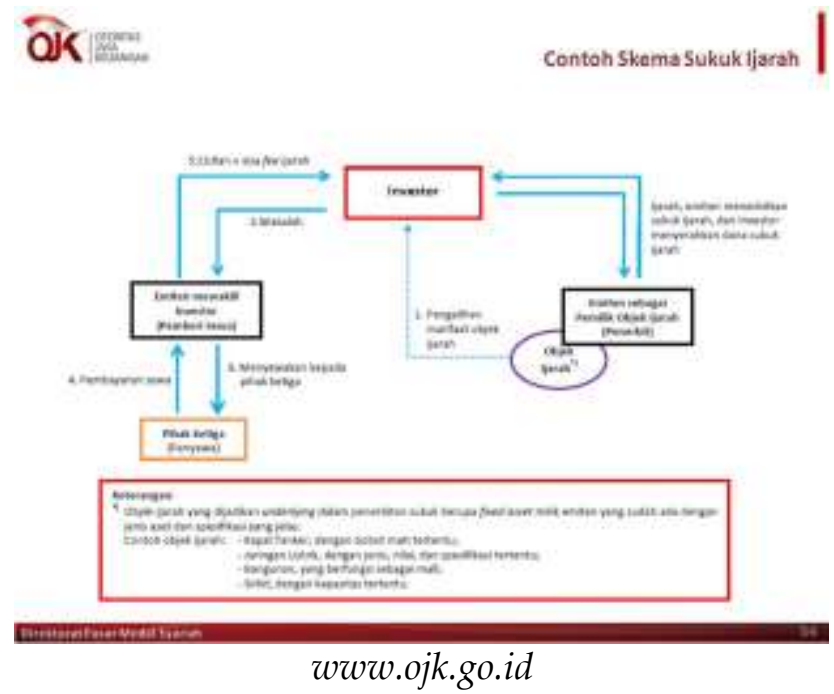

Penjelasan:

1. SPV dan Obligor melakukan transaksi jual beli asset, disertai dengan purchase dan sale underking di mana obligor menjamin untuk membeli kembali asset dari SPV dan SPV wajib menjual kembali asset kepada obligor, pada saat sukuk jatuh tempo dalam hal terjadi default.

2. SPV mendistribusikan penerbit sukuk kepada investor untuk membiayai asset.

3. Pemerintah menyewa kembali asset dengan melakukan perjanjian sewa (ijarah) dengan SPV untuk periode yang sama dengan tenor sukuk yang diterbitkan berdasarkan servicing agency agreement obligor ditunjuk sebagai agen yang bertanggung jawab atas perawatan asset.

4. Obligor membayar sewa (imbalan) secara periodic kepada SPV selama masa sewa.

5. SPV melalui agen yang ditunjuk akan mendistribusikan imbalan kepada investor.

6. Pada saat jatuh tempo, SPV melakukan penjualan kembali asset kepada obligor senilai nominal sukuk. Kemudian, hasil penjualan asset tersebut digunakan SPV untuk melunasi sukuk kepada investor. ${ }^{26}$

\section{Sukuk Mudharabah}

Menurut POJK No. 53/POJK.04/2015 tentang akad yang digunakan dalam penerbitan efek syariah di pasar modal, mudharabah (qiradh) adalah perjanjian (akad) kerjasama antara pihak pemilik modal (shahibul mal) dan pihak pengelola usaha (mudharib) dengan cara pemilik modal (shahibul ma) menyerahkan modal dan

\footnotetext{
${ }^{25}$ Muhammad Fadlilah Fauzulhaq, "Konsep, Teori Dan Praktik Obligasi Syariah," AlIqtishad: Journal of Islamic Economics (2015).

26-, “PERKEMBANGAN OBLIGASI SYARIAH (SUKUK) DI INDONESIA.”S
} 
pengelola usaha (mudharib) mengelola modal tersebut dalam suatu usaha. ${ }^{27}$ Sedangkan menurut Ayub, sukuk mudharabah adalah sertifikat yang menjelaskan kegiatan (bisnis) yang dijalankan dengan prinsip-prinsip mudharabah dengan menunjuk seorang partner atau suatu badan yang berfungsi sebagai mudharib untuk menjalankan manajemen bisnis tersebut. Dan juga, sukuk mudhrabah mendorong publik untuk ikut berpartisipasi dalam setiap kegiatan ekonomi investasi. ${ }^{28}$

Memungkinkan juga dari kedua belah pihak mempunyai modal dan daripada melakukan usaha sendiri, akan lebih efektif dan menguntungkan jika mereka bekerja sama. Bisa juga satu pihak yang mempunyai modal tidak mampu dalam artian tidak berpengalaman atau tidak sempat mengelolanya. Maka pihak kedua yang juga punya modal dengan pengalaman dan keahliannya mengelola kedua modal tersebut. Akan membuka pintu untuk bekerja sama dengan pihak yang ketiga. Bentuk seperti ini bermanfaat dan tidak ada halangannya dalam syariah. Jika mudharib dalam perjanjian mudharabah ini ada beberapa orang, menurut Imam Malik, maka keuntungan akan dibagi-bagi untuk mereka sesuai dengan kerja masing-masing. Hal ini, sama seperti syirkah abdan. ${ }^{29}$

Berikut ini contoh skema sukuk mudharabah adalah sebagai berikut:
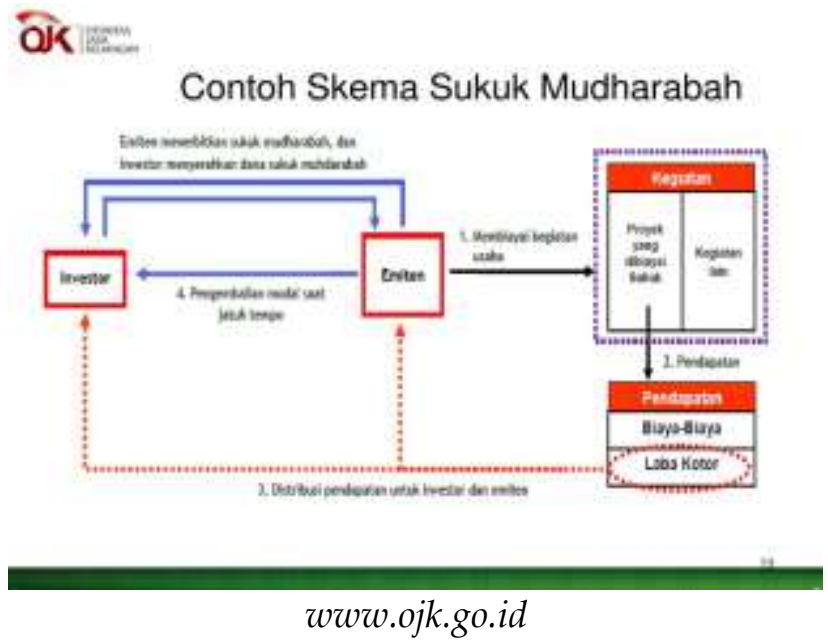

Penjelasan:

1. penerbit memproses penerbitan sukuk mudhrabah untuk keperluan mobilisasi modal dengan kadar tertentu.

2. Penerbit sebagai mudharib dan investor (shahibul mal) membuat kontrak mudharabah dengan perjanjian keuntungan yang disepakati.

3. Atas kontrak tersebut, terkumpul sejumlah modal mudharabah.

4. Penerbit menanamkan modal pada proyek perniagaan sebagai peluang baik dalam alternative perniagaan.

5. Atas investasi yang dilakukan mudharib dapat menghasilkan keuntungan tertentu.

\footnotetext{
27 OJK (2015), https: ojk.go.id, diakses pada tanggal 2 Juni 2020, pukul 20-26 WIB

${ }^{28}$ Siskawati, "Perkembangan Obligasi Syariah Di Indonesia: Suatu Tinjauan."

${ }^{29}$ Fauzulhaq, "Konsep, Teori Dan Praktik Obligasi Syariah."
} 
6. Keuntungan yang diperoleh dari perniagaan tersebut dapat dibagikan antara shahibul mal dan mudharib berdasarkan kesepakatan awal. ${ }^{30}$

\subsection{Dampak Sukuk Bagi Pasar Modal di Indonesia Dampak Negatif}

Perkembangan sukuk yang rendah, dapat berdampak terhadap regulasi yang mengatur proses penerbitan sukuk, tingkat sosialisasi dan juga investasi pada pasar modal syariah. Perkembangan sukuk yang rendah berdampak pada regulasi yang dikeluarkan oleh regulator. Laporan kajian pengembangan efek syariah Bapepam merekomendasikan perlunya dilakukan revisi peraturan tentang akad-akad yang digunakan dalam penerbitan efek syariah di pasar modal dengan menambahkan peraturan mengenai akad musyarakah dan akad ishtisna.

Selanjutnya, perlu dilakukan sosialisasi dan edukasi mengenai hal tersebut kepada pelaku pasar khususnya emiten, penjamin emisi efek, wali amanat, dan profesi penunjang pasar modal serta pelaku pasar modal lainnya yang turut terlibat dalam penerbitan sukuk. Dari akuntansi perlu disusum standar akuntansi yang mengatur tentang sukuk, termasuk dengan menggunakan akad musyarakah dan akad istisna. Sehingga dapat diberikan pedoman yang jelas dan baku sesuai dengan karakteristik sukuk sebagai efek syariah bagi emiten penerbit sukuk dan investor sukuk.

Selain berdampak pada regulasi, berdampak juga terhadap penambahan produk syariah pada pasar modal. Berdasarkan riset pengembangan produk syariah di pasar modal yang dilakukan Bapepam, bahwa perkembangan pasar modal di Indonesia saat ini masih sangat terbatas bila dibandingkan dengan produk konvensional. Terbatasnya produk syariah tersebut mengakibatkan alternatif investasi pembiayaan berbasis syariah menjadi sangat minim. ${ }^{31}$

Adapun dampak penurunan sukuk tersebut juga karena adanya permasalahan ketakpahaman masyarakat terhadap obligasi syariah ini. Hal ini menjadi permasalahan klasik yang bukan hanya terjadi pada sukuk saja, akan tetapi terjadi juga pada instrument investasi lainnya seperti saham syariah, reksadana syariah, asuransi syariah, pegadaian syariah dan sebagiannya, terutama system bagi hasil yang hanya dikenal oleh masyarakat kalangan atas atau kalangan pemodal saja. ${ }^{32}$

\section{Dampak Positif}

Adanya obligasi syariah (sukuk), sangat berdampak pada tingkat perekonomian di Indonesia. Penerbitan obligasi syariah dapat menjadi sebab terjadinya peningkatan pengaruh baik terhadap perusahaan. Selain itu, perusahaan pastinya akan memperoleh pengurangan bagian pendapatan yang dibayarkan untuk pajak dari perusahaan tersebut berupa tax shield. Adapun, penggunaan hutang piutang dapat

${ }^{30}$ Fatah, "Perkembangan Obligasi Syari'ah (Sukuk) Di Indonesia: Analisis Peluang Dan Tantangan."

${ }^{31}$ Kurniawati, "Analisis Perkembangan Sukuk (Obligasi Syariah) Dan Dampaknya Bagi Pasar Modal Syariah."

${ }^{32}$ Fatah, "Perkembangan Obligasi Syari'ah (Sukuk) Di Indonesia: Analisis Peluang Dan Tantangan." 
menyebabkan penurunan nilai saham, karena pengaruh dari biaya bunga dan biaya kepailitan yang mungkin bisa timbul dari hutang. ${ }^{33}$

Sehingga, jika suatu perusahaan menggunakan obligasi syariah dapat membantu pemasukan dana yang masuk pada perusahaan tersebut. Apabila tidak menggunakan obligasi syariah, sebenarnya perusahaan bisa berhutang. Akan tetapi berdampak kepada biaya bunga dari hutang tersebut.

Dampak positif juga, dalam obligasi syariah ini terhadap pemerintahan di Indonesia. Dengan adanya obligasi syariah, pemerintah dapat meminimalisir hutang piutang negara terhadap negara lain. Karena, jika pemerintah terus-menerus berhutang, maka bunga dari hutang tersebut juga akan bertambah banyak. Maka dari itu, adanya obligasi syariah ini dapat meminimalisir pengeluaran biaya terhadap Bungan hutang piutang negara.

\section{Kesimpulan}

Pasar modal di Indonesia berada di bawah naungan Otoritas Jasa Keuangan (OJK). Dan salah satu bagian dari pasar modal tersebut adalah obligasi syariah atau sukuk. Pada dasarnya sukuk merupakan salah satu bagian dari pasar modal yang merupakan instrument yang memberikan peluang bagi para investor muslim maupun non muslim di Indonesia untuk memulai berinvestasi. Sehingga, sukuk nantinya dapat dimanfaatkan untuk membangun perekonomian bangsa dan menciptakan kesejahteraan bagi masyarakat.

Perkembangan obligasi syariah di Indonesia mengalami perkembangan setiap tahunnya. Dari data-data terakhir yang dicantumkan dari tahun2016 sampai dengan tahun 2020 bulan April. Peningkatan terbanyak terjadi pada tahun 2019, sedangkan untuk tahun 2020 terjadi penurunan penerbitan obligasi syariah.

Dampak dari penerbitan obligasi syariah ini terbagi menjadi dua, yaitu dampak positif dan dampak negatif. Perkembangan obligasi syariah yang rendah dapat berdampak pada regulasi yang dikeluarkan oleh regulator. Hal ini bisa disebabkan oleh sosialisasi yang kurang kepada masyarakat.

Sedangkan, dampak positif dari perkembangan obligasi syariah adalah sangat berpengaruh terhadap perekonomian Indonesia. Hal ini bisa ditinjau, jika obligasi syariah meningkat, maka itu memberi angina segar bahwa obligasi syariah sudah diketahui oleh banyak kalangan, dan juga hutang-piutang khususnya pada pemerintahan dapat diminimalisir dengan adanya obligasi syariah ini.

Perkembangan obligasi syariah di Indonesia mengalami peningkatan setiap tahunnya. Walaupun, masih ada penurunan tingkat dalam penerbitan obligasi syariah. Untuk menanggulangi penurunan tersebut, perlu adanya sosialisasi ke seluruh masyarakat agar nantinya obligasi syariah ini dapat juga dirasakan manfaatnya secara bersama, tidak hanya kaum kapitalis saja.

Adanya obligasi syariah memberi dampak yang sangat besar terhadap perekonomian di Indonesia, terutama terhadap uang negara yang dikelola oleh pemerintah. Hadirnya obligasi syariah sebaiknya dapat dimanfaatkan secara maksimal, guna memberantas piutang negara Indonesia. Karena jika tidak bisa dimanfaatkan secara maksimal, maka negara masih saja dirugikan dengan biaya bunga dari hutang piutang yang terdahulu.

${ }^{33}$ Nur Indah Hardianti and Agus Widarjono, “Dampak Penerbitan Sukuk Dan Obligasi Konvensional Terhadap Return Saham Perusahaan Di Indonesia," Jurnal Ekonomi \& Keuangan Islam (2017). 


\section{Daftar Pustaka}

Muhammad Habibullah Aminy, Laili Hurriati. "PERKEMBANGAN OBLIGASI SYARIAH (SUKUK) DI INDONESIA." IQTISHADUNA (2018).

Aziz, M. Wahib. "WAKAF TUNAI DALAM PERSPEKTIF HUKUM ISLAM." International Journal Ihya' 'Ulum al-Din (2017).

Bakhri, Syaeful. "Minat Mahasiswa Dalam Investasi Di Pasar Modal." Al-Amwal : Jurnal Ekonomi dan Perbankan Syari'ah (2018).

Fadilla, Fadilla. "Pasar Modal Syariah Dan Konvensional." Islamic Banking: Jurnal Pemikiran dan Pengembangan Perbankan Syariah (2018).

Fatah, Dede Abdul. "Perkembangan Obligasi Syari'ah (Sukuk) Di Indonesia : Analisis Peluang Dan Tantangan." Al-'Adalah (2011).

Fauzan, M, and Dedi Suhendro. "Peran Pasar Modal Syariah Dalam Mendorong Laju Pertumbuhan Ekonomi Di Indonesia." Prosiding SENDI (2019).

Fauzulhaq, Muhammad Fadlilah. "Konsep, Teori Dan Praktik Obligasi Syariah." AlIqtishad: Journal of Islamic Economics (2015).

Hardianti, Nur Indah, and Agus Widarjono. "Dampak Penerbitan Sukuk Dan Obligasi Konvensional Terhadap Return Saham Perusahaan Di Indonesia." Jurnal Ekonomi E Keuangan Islam (2017).

Hariyanto, Erie. "BURGELIJK WETBOEK (Menelusuri Sejarah Hukum Pemberlakuannya Di Indonesia)." Al-Ihkam: Jurnal Hukum dan Pranata Sosial (2013).

Ibnu Elmi dan Jefri Tarantang, "Fatwa Majelis Ulama sebagai Solusi Permasalahan Umat di Indonesia", Proceding Majelis Ulama Indonesia (2019).

Juliati, Yenni Samri. "Peranan Pasar Modal Dalam Perekonomian Negara." HUMAN FALAH: Jurnal Ekonomi dan Bisnis Islam (2015).

Kurniawati, Devi Dwi. "Analisis Perkembangan Sukuk (Obligasi Syariah) Dan Dampaknya Bagi Pasar Modal Syariah." Al-Iqtishad (2013).

Malik, Ahmad Dahlan. "ANALISA FAKTOR - FAKTOR YANG MEMPENGARUHI MINAT MASYARAKAT BERINVESTASI DI PASAR MODAL SYARIAH MELALUI BURSA GALERI INVESTASI UISI." Jurnal Ekonomi dan Bisnis Islam (Journal of Islamic Economics and Business) (2017).

OJK (2015), https: ojk.go.id, diakses pada tanggal 2 Juni 2020, pukul 20-26 WIB

PERISTIWO, HADI. “ANALISIS MINAT INVESTOR DI KOTA SERANG TERHADAP INVESTASI SYARIAH PADA PASAR MODAL SYARIAH." ISLAMICONOMIC: Jurnal Ekonomi Islam (2016).

Rahmawati, Yuke. "Resosialisasi Investasi Keuangan Syariah." Al-Iqtishad: Jurnal Ilmu Ekonomi Syariah (2009).

Siskawati, Eka. "Perkembangan Obligasi Syariah Di Indonesia: Suatu Tinjauan." Jurnal Akuntansi \& Manajemen (2010).

Yafiz, Muhammad. "Saham Dan Pasar Modal Syariah: Konsep, Sejarah Dan Perkembangannya." Miqot: Jurnal Ilmu-Ilmu Keislaman (2008). 